\title{
Booklet on the use of personal protective equipment during the COVID-19 pandemic: preventing facial skin injuries
}

\author{
Cartilha de orientação sobre o uso \\ de equipamentos de proteção \\ individual durante a pandemia \\ de COVID-19: prevenindo \\ lesões cutâneas faciais
}

Breno César Diniz Pontes (i) Geraldo Magela Salomé (10*

Universidade do Vale do Sapucaí (Univás), Pouso Alegre, MG, Brazil

Date of first submission: February 18, 2021

Last received: April 15, 2021

Accepted: April 19, 2021

Associate editor: Janice Luisa Lukrafka Tartari

*Correspondence: salomereiki@univas.edu.br

\begin{abstract}
Introduction: In the year 2020, Brazilian and global public health systems were overwhelemend by COVID-19, a pandemic highly transmissible by droplets and contact, mainly in enclosed areas and hospital environments. Objective: Create a booklet to instruct health professionals on the use of personal protective equipment (PPE) and preventive measures for facial skin injuries during the SARS-CoV-2 pandemic. Methods: The study was conducted from June to September 2020, adopting the following steps: situational diagnosis; literature review of the main health science databases; content selection and survey; drafting texts; creating illustrations; and diagramming the manual. Results: After the literature review, 26 articles were selected for the booklet. The material was prepared by the authors of this article and reviewed by a professional in the biomedical field, with expertise in standardizing procedures and tissue injury innovations. The final version contains four chapters and three algorithms, one with step-by-step instructions on donning PPE, one on removal and one containing preventive measures for PPE-related injuries.

Conclusion: After an interactive review of the literature, a booklet was created that provides theoretical and practical foundations for health professionals on PPE donning and removal techniques, with a view to preventing facial injuries and COVID-19 infection.
\end{abstract}

Keywords: Coronavirus infections. Health promotion. Personal protective equipment. Pressure ulcer. 


\section{Resumo}

Introdução: No ano de 2020, a saúde pública brasileira e mundial passou por dificuldades com a chegada da COVID-19, pandemia altamente transmissivel por gotículas e contato, principalmente em locais fechados e ambientes hospitalares.

Objetivo: Construir uma cartilha para informar os profissionais de saúde sobre o uso de equipamentos de proteção individual (EPI) e medidas preventivas para lesões cutâneas faciais durante a pandemia da SARS-CoV-2. Métodos: A pesquisa foi desenvolvida entre os meses de junho e setembro de 2020, seguindo as etapas: diagnóstico situacional, revisão da literatura junto às principais bases de dados de ciências da saúde, seleção e fichamento do conteúdo, elaboração dos textos, criação das ilustrações, diagramação da cartilha. Resultados: Após revisão da literatura, 26 artigos foram selecionados para a construção cartilha. O material foi elaborado pelos autores do presente artigo e revisado por profissional da área de biomedicina, com atuação em padronização de procedimentos e inovações em lesões teciduais. A versão final da cartilha contém quatro capítulos e três algoritmos, sendo um com orientações passo a passo sobre paramentação, um sobre desparamentação e um contendo as medidas preventivas para lesões causadas pelo uso de EPIs. Conclusão: Após revisão interativa da literatura foi possivel construir uma cartilha que oferece fundamentação teórica e prática aos profissionais de saúde quanto ao emprego de técnicas de paramentação e desparamentação, possibilitando a prevenção de lesões faciais e de infecção por COVID-19.

Palavras-chave: Infecções por coronavírus. Promoção da saúde. Equipamento de proteção individual. Lesão por pressão.

\section{Introduction}

In 2020, the Brazilian and global health systems were overwhelmed by COVID-19. In January of that year, the World Health Organization declared an international public health emergency. ${ }^{1,2}$ COVID-19 is highly transmissible by droplets and contact, primarily in enclosed areas and hospitals. ${ }^{2,3}$ The use of personal preventive equipment (PPE) is neccesary to prevent health professionals from being contaminated and spreading the disease to others, ${ }^{4}$ but it is also important to be aware of the injuries resulting from the use of this equipment.
PPE is any device that health professionals use while caring for patients with infectious and contagious diseases, including gloves, goggles or face shield, masks, aprons and surgical caps. They are for individual usage and aim at protecting the physical integrity of the professional.

The media often reports on health professionals being infected by COVID-19 and sustaining pressure ulcers due to continuous improper use of PPE. ${ }^{5}$ Some health professionals report that the institution they work for provides PPE, but does not offer recycling courses related to the technique of donning and removing or protocols on how these professionals should give assistance to COVID-19 patients. ${ }^{5}$

In Brazil, according to the Ministry of Labor and Employment, employers are obliged to provide adequate PPE to minimize the risks individuals are exposed to, as well as conduct training programs on the correct use of this equipment upon employment and periodically therafter. ${ }^{6-9}$ Hospital investment in the training of health professionals on the proper use of PPE and caring for patients with COVID-19 is effective in avoiding contamination and preventing pressure ulcers caused by the equipment. ${ }^{9}$

In April 2016, the National Pressure Ulcer Advisory Panel announced a change in pressure ulcer terminology to include medical device-related pressure injuries (MDRPI). These injuries are sustained when professionals use devices designed for dignostic or therapeutic purposes. ${ }^{10-13}$ The prolonged or incorrect use of masks, goggles and face shields is responsible for friction forces and constant pressure on the tissues, leading to injury. ${ }^{11,12}$

Nursing care should be provided to prevent MDRPI via daily inspection of the skin, as well as careful removal and placement of the devices to reduce frictional and shear forces without changing the safety level of the PPE. The impact on tissues could be reduced and the response capacity of the skin to aggression increased, ${ }^{10,13}$ but the institutions must implement protocols, manuals, booklets and pamphlets, in addition to training their professionals on how to safely put on (don) and remove (doff) PPE.

Studies report that didactic materials improve the knowledge, satisfaction, acceptance and adherence to treatment and preventive measures of professionals, patients and caregivers, with the teaching-learning process occurring through professional-patient interaction. ${ }^{14-16}$ In this respect, it is important to create and validate educational tools, including manuals, booklets and 
protocols that provide appropriate information on PPE use as well as preventive actions and therapeutic conduct for MDRPI.

It is believed that using the booklet developed in this study can contribute to the health education of those on the front line of COVID-19, offering information on the use of PPE and preventive measures for injuries sustained through the use of these devices. This will enable professionals to provide care under safer conditions for patients and themselves.

\section{Methods}

This is a descriptive study aimed at compiling a booklet to guide health professionals on how to don and remove PPE and on preventive measures against skin injuries during the SARS-CoV-2 pandemic.

The process of compiling an educational booklet involved the following phases: situational diagnosis, content survey, compiling and assembling the educational booklet (Figure 1). ${ }^{14-16}$

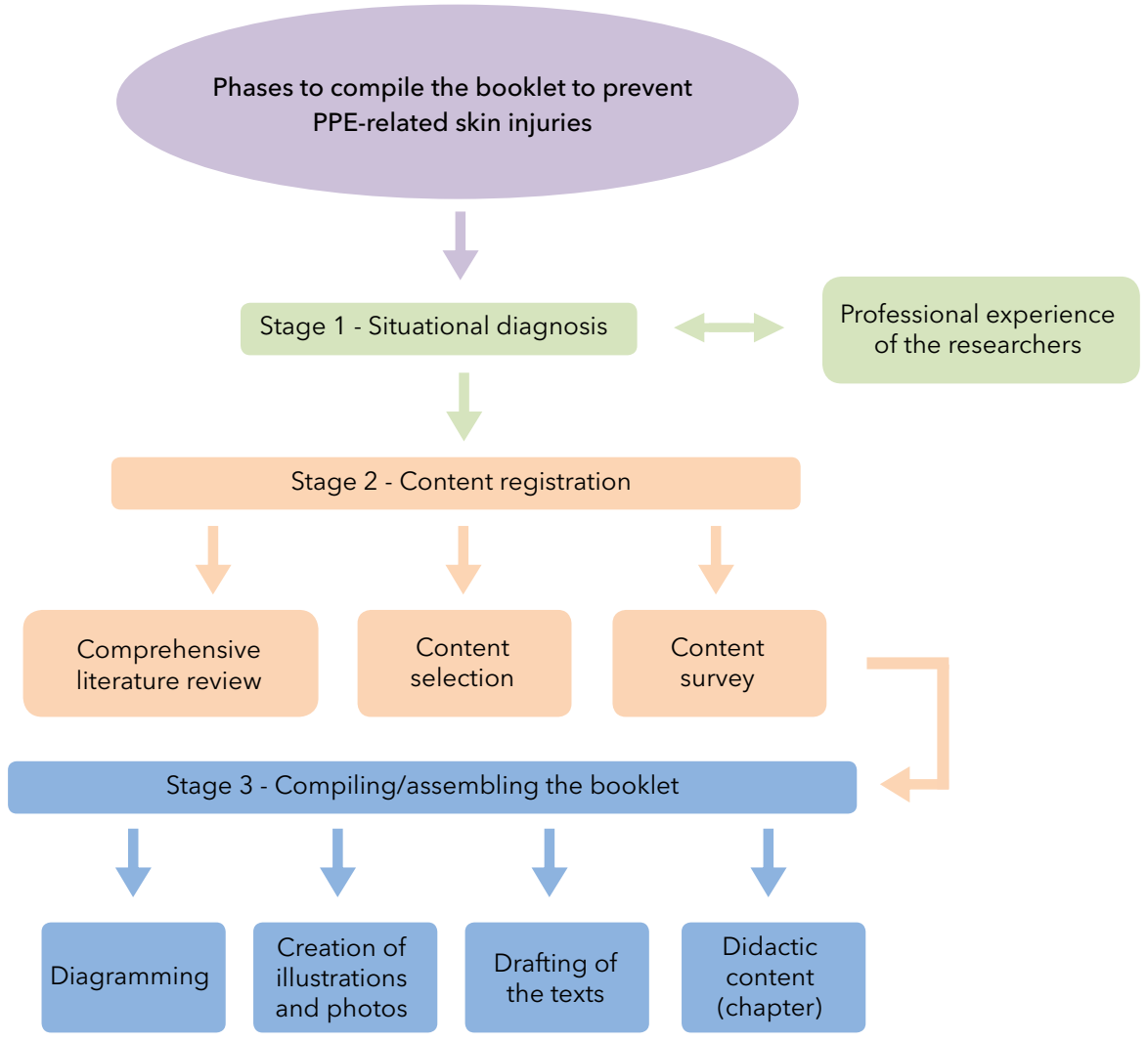

Figure 1 - Compilation of the booklet entitled "Personal protective equipment during the COVID-19 pandemic: preventing skin injuries". Pouso Alegre, MG, Brazil, 2020.

\section{First stage: Situational diagnosis}

The idea for this booklet arose from clinical practice observations, since some frontline professionals in the COVID-19 pandemic have difficulty using PPE correctly, putting them at risk of contamination and developing MDRPI.

\section{Second stage: Content survey}

To compile the booklet, a comprehensive literature review was performed in the health science databases PubMed, SciELO and LILACS, for articles published between 2015 and 2020. ${ }^{17}$ The descriptors used were COVID-19, medical device-related pressure ulcer, 
equipment and provisions, in Portuguese, English and Spanish. The search strategy for each language was determined by the combination of the descriptors and the Boolean operator "AND", such as COVID-19 AND pandemics, medical device-related pressure ulcer AND equipment and provisions.

Initially, 12,535 articles were identified, 4,523 of which were excluded for being duplicates in the databases. Thus, the titles and abstracts of 8,012 and 163 articles were read, respectively, resulting in 112 articles being read in their entirety. Of these, 51 were excluded for not answering the guiding questions, culminating in 26 articles selected ${ }^{17}$ to compile the booklet.

This survey ${ }^{17}$ was used to compile the educational bookletin three stages. The first stage included the definition (pandemic, SARS-CoV-2, COVID-10), respiratory etiquette, signs and symptoms of SARS-CoV-2. In the second, the PPE used by health professionals is described, as well as techniques and recommendations for PPE use when dealing with COVID-19 patients, according to the type of treatment provided by the health professional. In the third stage, the pressure ulcer was defined by medical device, measures to prevent PPE-related ulcers were described as well as the proper skin care before and after PPE use.

\section{Third stage: Compiling/assembling the booklet}

The illustrations and preliminary content were developed, edited and diagrammed, in line with the criteria relative to content, structure/organization, language, layout design, cultural sensitivity and adaptations for the older population. This process was carried out by a professional with experience in the area.

The images were selected from the internet, converted into drawings and processed in the Corel Draw $^{\circledR}$ program, version 17, creating the first version of the booklet between August and October 2020.

\section{Results}

The material was reviewed by a biochemist (Fernandes ART), experienced in standardizing procedures and tissue injury innovations. The final version of the booklet, entitled "Personal protective equipment during the COVID-19 pandemic: preventing skin injuries", contains four chapters and three algorithms, one with step-by-step instructions on donning PPE, one on removal and one containing preventive measures for PPE-related injuries. Standard formatting was used ( $21 \mathrm{~cm}$ high by $15 \mathrm{~cm}$ wide), with each page containing up to five illustrations, for a total of 63 pages and 201 illustrations.

Chapter 2, "SARS CoV-2 pandemic", addresses the following issues: definition (pandemic, SARS-CoV-2, COVID-10), respiratory etiquette, and signs and signals of SARS-CoV-2. In chapter 3, "Use of personal protective equpment by health professionals", the type of PPE are described (Figure 2), in addition to donning and removal techniques (Figure 3 ) and recommendations on the use of PPE when dealing with COVID-19 patients, according to the type of treatment. Chapter 4, "Medical device-related pressure injuries (MDRPI) during the SARS CoV-2 pandemic", contains the definition of MDRPI (Figure 4), measures to prevent these injuries, skin care before and after the use of PPE, and the devices used to prevent and treat injuries caused by this equipment (Figure 5).

\section{PERSONAL PROTECTIVE EQUIPMENT} FOR NONINVASIVE COVID-19 CARE

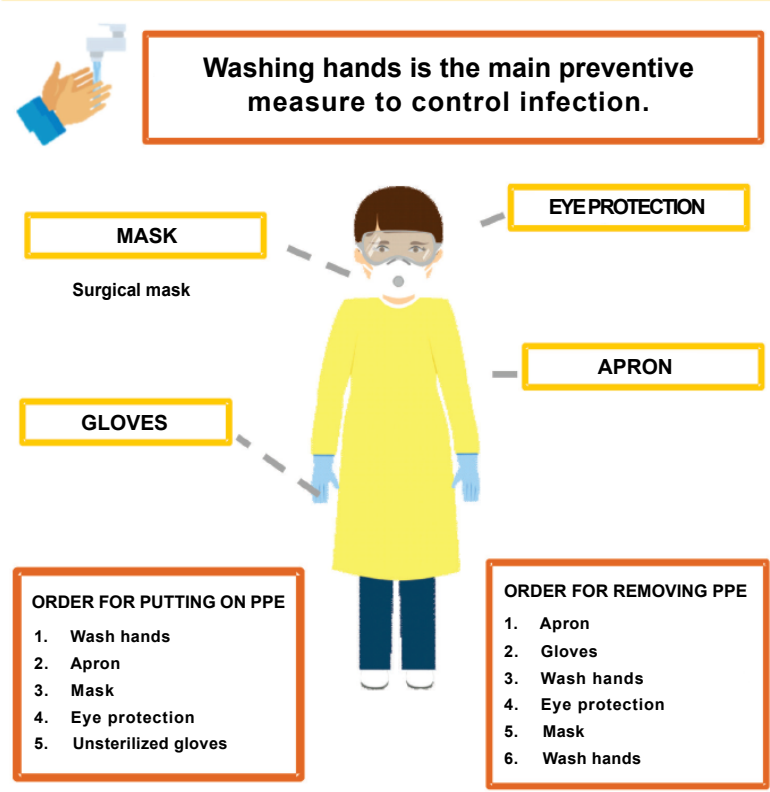

Figure 2 - Types of PPE used by health professionals, according to Guideline $02 / 2020 .^{18}$ 
Equipamentos de Proteçăo Individual: Prefenindo Lesōes de pele

Store the mask in a paper bag, as illustrated in Figure 14.

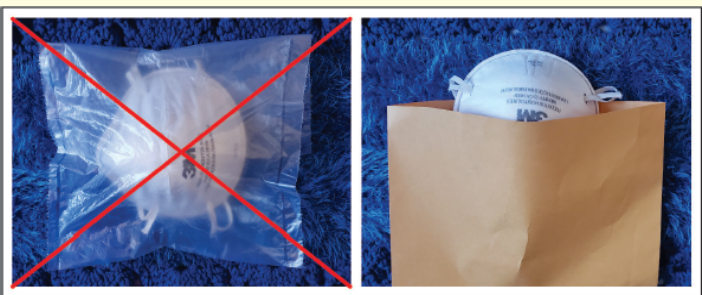

Figure 14 - Correct storage of the $\mathrm{N}-95$.

3.3 Surgical cap

Surgical caps and hoods protect against particles that may contaminate professionals and prevent hair or other working materials from falling.

3.3.1 Technique for surgical cap use (Figure 15)

- Place the surgical cap or hood on the head, from the forehead towards the back of the neck.

- Comfortably cover all the hair and ears.

- Replace the cap or hood when damp.

Figure 3 - Information on the correct use of storing the N-95 mask and surgical cap use.

Universidade do Vale do Sapuca

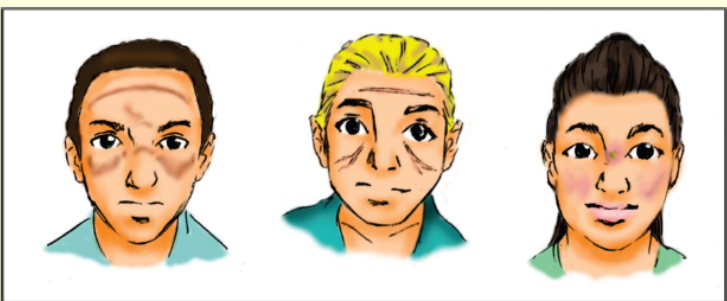

Figure 24 - Medical device-related pressure injury (MDRPI) caused by the use of masks, goggles and face shields.

Facial pressure injuries in health professionals are generally caused by the use of medical devices. PPE, such as masks, goggles and gloves, also cause hives, skin irritation, dry skin and contact dermatitis, denominated medical device-related pressure injuries.

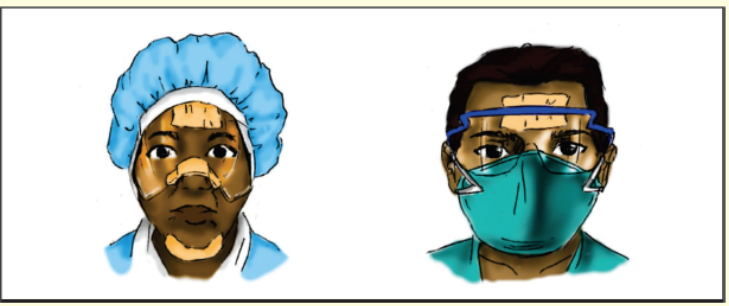

Figure 25 - Regions affected by the continuous use of PPE.

Figure 4 - Medical device-related devices during the COVID 19 pandemic.

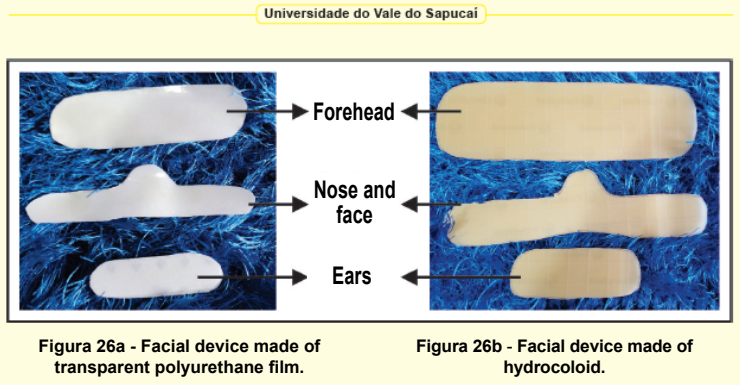

2 - The use of covering (silicone foam, transparent polyurethane and hydrocolloid) to prevent medical device-related pressure injury, commonin clinical practice, should exhibit level of evidence B. The material should be thin, not cause injury during removal, absorb moisture, be adaptable to the face contours, and guarantee correct mask seal. Figure 26 shows the types of materials used to treat PPE injuries.

3 - Professionals should don the mask or face shield carefully, without applying pressure or excessive forceto ensure an optimal seal. Otherwise, the skin will be subjected to friction, causing discomfort and probable injury.

4 - The professionals should adjust the mask or shield to the shape of their nose/face before definitively fixing the PPE.

5 - It is important to assess all the contact zones between the PPE and the skin. The nose, cheeks, forehead and area behind the ear are zones of friction/irritation.

Figure 5 - Preventing medical device-related pressure injury.

\section{Discussion}

The booklet was compiled after a comprehensive literature review and identification of evidence-based articles. ${ }^{17}$ Analysis of bibliographic material revealed that this is a valuable instrument for health professionals, given that it promotes workplace safety.

The booklet provides guidance for frontline professionals treating people with COVID-19 on protecting themselves from contamination and avoiding transmitting the infection to other patients under their care. Another important aspect of this instrument is instructing them on preventing PPE-related injuries.

Several studies report that manuals, booklets and protocols should be created after a literature review. This will enable professionals to develop evidencebased educational material, facilitating implementation in clinical practice and providing systematized and personalized care, with less risk and harm to the patient and no adverse events. ${ }^{12,13,19,20}$

The written material reinforces the information and oral discussions and helps in clinical decisions. Educational technologies, whatever the situation, 
improve user knowledge and satisfaction. They should contain simple, clear and easy-to-understand vocabulary. ${ }^{21,22}$

It is believed that the material developed in the present study can benefit health professionals, since it uses clear and objective language. It also contains instructions on correct PPE donning and removal techniques, in addition to skin care before and after PPE use.

\section{Conclusion}

After a comprehensive literature review, the booklet entitled "Personal protective equipment during the COVID-19 pandemic: preventing skin injuries" was created to provide a theoretical and practical framework for health professionals and contribute to standardizing the PPE donning and removal technique, thereby allowing professionals to prevent facial pressure injuries and avoid being infected by COVID-19, resulting in improved individualized and personalized care.

\section{Acknowledgements}

The authors thank Aline Rodrigues Tenório Fernandes for revising the booklet material, as well as Cristiane Reis da Silva Costa, José Dias da Silva Neto, Lucilene Marques and Sergio Aguinaldo de Almeida.

\section{Authors' contributions}

GMS interpreted the findings and BCDP wrote the article. Both authors contributed to the conception of the study and approved the final version.

\section{References}

1. Rothan HA, Byrareddy SN. The epidemiology and pathogenesis of coronavirus disease (COVID-19) outbreak. J Autoimmun. 2020;109:102433. DOI

2. Medeiros EAS. A luta dos profissionais de saúde no enfrentamento da COVID-19. Acta Paul Enferm. 2020;33:e-EDT20200003. DOI
3. Oliveira AC, Lucas TC, Iquiapaza RA. What has the COVID-19 pandemic taught us about adopting preventive measures? Texto Contexto Enferm. 2020;29:e20200106. DO|

4. Taminato M, Mizusaki-Imoto $A$, Saconato $H$, Franco ESB, Puga $M E$, Duarte $M L$, et al. Máscaras de tecido na contenção de gotículas respiratórias - revisão sistemática. Acta Paul Enferm. 2020;33:eAPE20200103. DOI

5. Oliveira AC. Desafios da enfermagem frente ao enfrentamento da pandemia da Covid19. Rev Min Enferm. 2020;24:e1302. DOI

6- Brasil. Norma Regulamentadora NR6 - Equipamento de Proteção Individual - EPI. Brasília: Diário Oficial da União; 8 jun 1978. Full text link

7. Carvalho JFS, Chaves LDP. Supervisão de enfermagem no uso de equipamento de proteção individual em um hospital geral. Cogitare Enferm. 2010;15(3):513-20. Full text link

8. Aranha JR, Aroni P, Pinhatti EDG, Ribeiro RP. Exposição à fumaça cirúrgica: como se proteger? J Nurs UFPE. 2020;14: e243963. Full text link

9. Oliveira HC, Souza LC, Leite TC, Campos JF. Personal Protective Equipment in the corona virus pandemic: training with Rapid Cycle Deliberate Practice. Rev Bras Enferm. 2020;73(Suppl 2):e20200303. DOI

10. Cavalcanti EC, Kamada I. Medical-device-related pressure injury on adults: an integrative review. Texto Contexto Enferm. 2020;29:e20180371. DOI

11. Ferreira DH, Teixeira MLO, Branco EMSC. Cuidados de enfermagem para a prevenção de lesão de pele por adesivos em feridas cirúrgicas. Cienc Cuid Saude. 2017;16(2):1-7. DOI

12. Gefen A, Alves P, Ciprandi G, Coyer F, Milne C, Ousey K, et al. An international consensus on device-related pressure ulcers: SECURE prevention. Br J Nurs. 2020.12;29(5):S36-8. DOI

13. Moraes JT, Borges EL, Lisboa CR, Cordeiro DCO, Rosa EG, Rocha NA. Conceito e classificação de lesão por pressão: atualização do National Pressure Ulcer Advisory Panel. Enferm Cent O Min. 2016;6(2):2292-306. DOI 
14. Vieira RHG, Erdmann AL, Andrade SR. Vacinação contra influenza: construção de um instrumento educativo para maior adesão dos profissionais de enfermagem. Text Context Nursing. 2013;22(3):603-9. DOI

15. Salomé GM, Cunha AL, Pereira AP, Miranda FD, Alves JR. Educational handbook for healthcare professionals: Preventing complications and treating peristomal skin. J Coloproctol (Rio J). 2019;39(4):332-8. DOI

16. Torres HC, Candido NA, Alexandre LR, Pereira FL. O processo de elaboração de cartilhas para orientação do autocuidado no programa educativo em Diabetes. Rev Bras Enferm. 2009; 62(2):312-6. DO।

17. Salomé GM. Algoritmo para paramentação, desparamentação e prevenção de lesões faciais: covid-19. Rev Enferm Contemp. 2021;10(2):1-14. DOI

18. Freitas MGG. Orientação $n^{\circ} 002 / 2020$ de 25/01/2020 atualizada a 10/02/2020. Infecção pelo novo Coronavírus (2019nCoV). Lisboa: Serviço Nacional de Saúde; 2020. Fulltext link
19. Cunha DR, Salomé GM, Massahud Jr MR, Mendes B, Ferreira LM. Development and validation of an algorithm for laser application in wound treatment. Rev Latino-Am Enfermagem. 2017;25:e2955. DOI

20. Santos AC, Dutra RAA, Salomé GM, Ferreira LM. Construction and internal reliability of an algorithm for choice cleaning and topical therapy on wounds. J Nurs UFPE. 2018;12(5):1250-62. DOI

21. Salomé GM, Ferreira LM. Developing a mobile app for prevention and treatment of pressure injuries. Adv Skin Wound Care. 2018;31(2):1-6. DOI

22. Cunha JB, Dutra RAA, Salomé GM, Ferreira LM. Computational system applied to mobile technology for evaluation and treatment of wounds. J Nurs UFPE. 2018; 12(5):1263-72. DOI 